\title{
Occurrence of Virulence Genes Associated with Diarrheagenic Escherichia coli Isolated from Raw Cow's Milk from Two Commercial Dairy Farms in the Eastern Cape Province, South Africa
}

\author{
Lesley-Anne Caine ${ }^{1}$, Uchechukwu U. Nwodo ${ }^{1}$, Anthony I. Okoh ${ }^{1}$, Roland N. Ndip ${ }^{1,2}$ \\ and Ezekiel Green ${ }^{1, *}$
}

1 Departments of Biochemistry and Microbiology, University of Fort Hare, Private Bag X1314, Alice 5700, South Africa; E-Mails: 200906584@ufh.ac.za (L.C.); UNwodo@ufh.ac.za (U.U.N.); AOkoh@ufh.ac.za (A.I.O.); RNdip@ufh.ac.za (R.N.N.)

2 Department of Microbiology and Parasitology, Faculty of Science, University of Buea, P.O. Box 63, Buea, Cameroon; E-Mail: ndip3@yahoo.com

* Author to whom correspondence should be addressed; E-Mail: EGreen@ufh.ac.za; Tel.: +27-406-022-682 (ext. 2682); Fax: +27-866-219-191.

External Editor: Paul B. Tchounwou

Received: 8 September 2014; in revised form: 5 November 2014 / Accepted: 10 November 2014 / Published: 18 November 2014

\begin{abstract}
Escherichia coli remains a public health concern worldwide as an organism that causes diarrhea and its reservoir in raw milk may play an important role in the survival and transport of pathogenic strains. Diarrheagenic E. coli strains are diverse food-borne pathogens and causes diarrhea with varying virulence in humans. We investigated the prevalence of pathogenic $E$. coli in raw milk from two commercial dairy farms. Four hundred raw milk samples, 200 from each dairy farm, were screened for the presence of fliCH7, eagR, ial, eagg, lt, and papC genes. In dairy farm A, $100 \mathrm{E}$. coli were identified based on culture, oxidase and Gram staining, while 88 isolates from dairy farm B were identified in the same manner. Gene detection showed fliCH7 27 (54\%) to be the highest gene detected from farm A and $l t 2(4 \%)$ to be the lowest. The highest gene detected in dairy farm B was fliCH7 16 $(43.2 \%)$ and papC $1(2.7 \%)$ was the least. The amplification of pathogenic genes associated with diarrheagenic $E$. coli from cows' raw milk demonstrates that potentially virulent $E$. coli strains are widely distributed in raw milk and may be a cause of concern for human health.
\end{abstract}


Keywords: Escherichia coli; virulence markers; raw milk

\section{Introduction}

Escherichia coli is a commensal in the intestines of a variety of animals, including man. However, diarrhoeal diseases caused by the pathogenic strains of this species can be debilitating and sometimes fatal [1]. The mechanisms involved in the disease processes and virulence attributes have been used to differentiate pathogenic strains of $E$. coli and is divided into diarrhoeal pathogens causing diarrhoea (diarrhoeagenic E. coli) and extraintestinal E. coli (ExPEC) [2] based on the site of infection. However, E. coli pathotypes may cause three main types of infections: sepsis/meningitis, enteric and diarrheal diseases, and urinary tract infections [3].

Enteric pathogens have been broadly divided into enterotoxigenic E. coli (ETEC), enteropathogenic E. coli (EPEC), enteroinvasive E. coli (EIEC), enterohaemorrhagic E. coli (EHEC) have been established, while enteroaggregative $E$. coli (EAEC), diffusely adherent E. coli, necrotoxic E. coli, and cell-detaching E. coli [4]. Two additional E. coli pathotypes, collectively called extraintestinal pathogenic E. coli [5] are responsible for extraintestinal infections. Extraintestinal pathogenic E. coli consist of uropathogenic E. coli (UPEC) causing urinary tract infections, E. coli strains that causes septicaemia, and neonatal meningitis associated E. coli (MNEC) [6]. In all E. coli isolates the uidA gene, which codes for the $\beta$-glucuronidase enzyme, serve as a target for fluorogenic PCR detection of E. coli in approximately $95 \%$ of naturally occurring E. coli.

Epidemiology, treatment, pathogenesis, and clinical manifestations can be used to preliminary identify each pathotype [7]. However, more researchers are using molecular methods such as polymerase chain reaction to identify pathotypes. EPEC pathotype has been sub-divided into typical and atypical EPEC depending on their adhesion mechanisms in human epithelial cells [8]. Typical EPEC's adhesion is mediated by $b f p A$ found in the EPEC adhesion factors type plasmid (EAF) that makes the organism to adhere to human epithelia cells in a localized manner [8]. The presence of locus of enterocyte effacement has been used to identify atypical EPEC. This locus codes for the gene of attaching and effacing, eae. This gene enables the bacteria to adhere and destroy human intestinal enterocytes [9].

Enteroaggregative E. coli, producing enteroaggregative mechanisms that promotes diarrhea in humans are coded for by the eagR, the master regulator of EAEC virulence, controls the expression of adherence factors, a dispersin protein, and a cluster of genes encoded on the EAEC chromosome. One of the most common clinical manifestations of EAEC infection is watery diarrhea, usually unaccompanied by blood or mucus.

EIEC is characterized by the destruction of the colonic epithelium caused by the inflammatory response induced upon invasion of the mucosa by EIEC [10] using the ial (marker for invasivity) gene. ETEC are important causes of total diarrheal episodes worldwide. These strains cause diarrhea through the action of enterotoxins: the heat-labile (LT) and heat-stable (ST) enterotoxins. Some strains may express an LT only, an ST only, or both an LT and an ST coded for by lt and st in the plasmid. Adenylate cyclase is activated by LT, causing diarrhea while guanylyl cyclase in intestinal epithelial 
cells is activated by ST causing fluid secretion. E. coli strains that are capable of producing both LT and ST toxins (ETEC) can cause severe diarrhea [11].

Enterohaemorrhagic E. coli (EHEC) is associated with foodborne outbreaks in the developed world and can cause bloody diarrhoea, haemorrhagic colitis (HC) and the Haemolytic Uraemic Syndrome (HUS) due to the elaboration of Shiga toxin (Stx). In EHEC strains, stx-genes are typically found in transmissible lambdoid bacteriophages [12]. Other virulence factors such as membrane protein intimin, encoded by the eae gene, fliCH7 encoding flagella antigen $\mathrm{H} 7$ and enterohaemolysin, encoded by the $H l y A$ gene [13] have been identified.

Virulence factors such as toxins (cytotoxic necrotizing factors and hemolysin), adhesins (P fimbriae, afrimbriae, type 1 fimbriae, S and F1C fimbriae), polysaccharide coatings (group II capsules) and siderophores (the aerobactin system) [14,15], associated UPEC are thought to be responsible for the pathogenic potential of the organism. Specific adhesins that mediates specific adhesion can be differentiated based on the receptor binding specificity. The most significant mannose-resistant adhesins are the $\mathrm{P}$ fimbriae encoded by E. coli pap (pyelonephritis associated pilus) operon. However, they are expressed by few E. coli serotypes [16]. Uropathogenic E. coli strains have been identified by detecting urovirulence factors including those mentioned earlier using conventional PCR [15].

Discriminating various $E$. coli pathotypes from cattle and their products have been greatly studied in the last two decades with biomolecular techniques favoured over serology in detection of E. coli pathotypes because they are more sensitive and specific [17-21]. It therefore became the objective of this study to find the prevalence of E. coli virulence genes from two dairy farms in the Eastern Cape, South Africa.

\section{Experimental Section}

\subsection{Study Sites}

Eastern Cape Province is one of the poorest and second largest provinces in South Africa and mainly comprised of rural settlements, it is also the "livestock" province of the country carrying $46 \%$ of South Africa's goats, $28 \%$ sheep, and $21 \%$ cattle. Dairy farm A has been in operation since 2007, it has 800 dairy cows and produces about 10,000 L of milk per day which is bought by one of the biggest milk companies in South Africa. Dairy farm A has a rotary milking parlour whereas dairy farm B has an in-line milking system. Both dairy farms are located in the Eastern Cape Province. Dairy farm B has been in operation since 2008, it has 600 dairy cows and produces about $8000 \mathrm{~L}$ of milk per day.

\subsection{Isolation and Identification}

We collected 400 raw milk samples from individual lactating cows showing clinical and subclinical signs of mastitis from the chosen two dairy farms (200 (100 from clinical and 100 from subclinical mastitis) from farm A and 200 (100 from clinical and 100 from subclinical mastitis) from farm B). Clinical mastitis occurs when visible signs of inflammation are observed in the udder of the cow or the teats; while Subclinical mastitis is more subtle in that no signs of infection are visible this requires regular monitoring and laboratory testing. Subclinical mastitis was determined using California 
Mastitis Test. Samples were collected according to the in-house procedure on each farm. Briefly, each milking station has a small collection bottle with a little hole for sample collection that is open and closed using a tap. The bottles are washed after each individual cow's milking session. The samples were collected from that tap. The samples were cultured on selective medium Violet red bile-mug agar (Merck, Johannesburg, South Africa) and incubated at $37{ }^{\circ} \mathrm{C}$ for $24 \mathrm{~h}$. The plates were checked under UV light at 360-370 $\mathrm{nm}$ after $24 \mathrm{~h}$ of incubation. Light blue fluorescence indicates the presence of E. coli [22,23]. Biochemical tests including Gram staining, catalase and oxidase test were performed. Those organisms that were Gram negative, catalase positive and oxidase negative were identified using API 20E (BioMerieux, Marcy I'Etiole, France) following manufacturer's instructions.

\subsection{DNA Extraction}

DNA was extracted from identified E. coli and from a positive control strains for E. coli (ATCC 8739, South African Bureau of Standards (SABS), No. ESC 20) purchased from South African Bureau of Standards, Pretoria, South Africa. DNA extraction was done following the method of Maugeri et al. [24] and Lopez Saucedo et al. [25]. Briefly, single colonies of presumptive E. coli grown overnight at $37{ }^{\circ} \mathrm{C}$ on EMBA plates were picked, suspended in $200 \mu \mathrm{L}$ of sterile distilled water, vortexed for $2 \mathrm{~min}$ using MS2 Minishaker (Digisystem Laboratory Instruments Inc., New Taipei City, Taiwan). The cells were then centrifuged for $10 \mathrm{~min}$ at 13,000 rpm (ThermoFisher Scientific, Schwerte, Germany). Five hundred microliters $(500 \mu \mathrm{L})$ distilled water was pipetted into the eppendorf tubes, vortexed and the cells were lysed using a heat on Dri-Block DB.2A (Techne, Johannesburg, South Africa) for 15 min at $100{ }^{\circ} \mathrm{C}$. The cell debris were removed by centrifugation at 10,000 rpm for $5 \mathrm{~min}$ using a MiniSpin microcentrifuge (ThermoFisher Scientific). The supernatant was used as a template in the PCR assay immediately after extraction.

\subsection{Detection of Virulence Genes in E. coli Isolates}

Oligonucleotide primers targeting the uidA gene were used to confirm the isolates in the polymerase chain reaction with the conditions as shown in Table 1. PCR assay was carried out in a 25 $\mu \mathrm{L}$ reaction volume containing a $24 \mu \mathrm{L}$ of $2 \times$ master mix (containing $0.05 \mathrm{U} / \mu \mathrm{L}$ of Taq DNA polymerase, reaction buffer, $4 \mathrm{mM} \mathrm{MgCl}_{2}$, and $0.4 \mathrm{mM}$ of each $\mathrm{dNTP}$ ) and $1 \mu \mathrm{L}$ of template DNA. Oligonucleotide primers targeting the fliCH7 gene encoding for structural flagella antigen $\mathrm{H} 7$ in Enterohemorrhagic E. coli, eagR gene encoding for antiaggregative protein of Enteroaggregative $E$. coli, ial gene encoding for invasion-associated locus of Enteroinvasive E. coli, eae gene encoding for Enteropathogenic $E$. coli intimin, $l t$ gene encoding for heat-labile toxins found in Enterotoxigenic $E$. coli and papC gene characterizing uropathogenic $E$. coli were used in the polymerase chain reaction following the conditions in Table 1. The positive control for uidA was E. coli ATCC 8739 (SABS No. ESC 20) purchased from the South African Bureau of Standards in Pretoria; positive control for the eagR gene is DSM 10974, DSM 10973 for $l t$ gene, DSM 4618 for papC, DSM 8695 for eae gene and DSM 9025 for ial gene and where all purchased from Leibniz-Institut DSMZ-Deutsche Sammlung von Mikroorganismen und Zellkulturen, Braunschweig, Germany. However the positive control for fliCh7 gene (EHEC) was not available at the time of purchase. 
Table 1. Primer sequences and expected size of PCR amplified gene targets of the pathogenic strains of Escherichia coli.

\begin{tabular}{|c|c|c|c|c|c|}
\hline $\begin{array}{l}\text { Target } \\
\text { Strain }\end{array}$ & $\begin{array}{l}\text { Target } \\
\text { Gene }\end{array}$ & Primer Sequence $\left(5^{\prime}-3^{\prime}\right)$ & Conditions & $\begin{array}{c}\text { Amplicon } \\
\text { Size (bp) } \\
\end{array}$ & References \\
\hline E. coli & UidA & $\begin{array}{l}\text { AAAACGGCAAGAAAAAGCAG } \\
\text { ACGCGTGGTTAACAGTCTTGCG }\end{array}$ & $\begin{array}{l}\text { An initial } 2 \text { min of denaturation at } 94{ }^{\circ} \mathrm{C} \text { followed by } 25 \text { cycles of } 94{ }^{\circ} \mathrm{C} \\
\text { for } 1 \mathrm{~min}, 58{ }^{\circ} \mathrm{C} \text { for } 1 \mathrm{~min} \text { and } 72{ }^{\circ} \mathrm{C} \text { for } 2 \mathrm{~min} \text {. Amplified products were } \\
\text { held at } 4{ }^{\circ} \mathrm{C} \text { after amplification. }\end{array}$ & 147 & [26] \\
\hline EHEC & flicH7 & $\begin{array}{l}\text { TACCATCGCAAAAGCAAC TCC } \\
\text { GTCGGCAACGTTAGTGATACC }\end{array}$ & $\begin{array}{l}\text { Initial denaturation at } 95^{\circ} \mathrm{C} \text { for } 15 \text { min followed by } 35 \text { cycles of heat } \\
\text { denaturation at } 94^{\circ} \mathrm{C} \text { for } 45 \mathrm{sec} \text {, primer annealing at } 55^{\circ} \mathrm{C} \text { for } 45 \mathrm{sec} \text { and } \\
\text { DNA extension at } 68^{\circ} \mathrm{C} \text { for } 2 \mathrm{~min} \text {. After the last cycle the samples were } \\
\text { kept at } 72^{\circ} \mathrm{C} \text { for } 5 \mathrm{~min} \text { to complete synthesis of all strands. }\end{array}$ & 230 & [27] \\
\hline EIEC & Ial & $\begin{array}{l}\text { CTGGATGGTATGGTGAGG } \\
\text { GGAGGCCAATTATTTCC }\end{array}$ & $\begin{array}{l}1 \text { cycle for } 2 \min \text { at } 50{ }^{\circ} \mathrm{C}, 1 \text { cycle for } 5 \min \text { at } 95{ }^{\circ} \mathrm{C}, 40 \text { cycles for } \\
45 \sec \text { at } 95{ }^{\circ} \mathrm{C}, 45 \sec \text { at } 55^{\circ} \mathrm{C} \text { and } 45 \sec \text { at } 72{ }^{\circ} \mathrm{C} \text { and a final extension } \\
\text { step for } 10 \mathrm{~min} \text { at } 72{ }^{\circ} \mathrm{C} \text { to complete synthesis of all strands. }\end{array}$ & 700 & [28] \\
\hline EAEC & $\operatorname{Eag} R$ & $\begin{array}{l}\text { AGACTCTGGCGAAAGACTGTATC } \\
\text { ATGGCTGTCTGTAATAGATGAGAAC }\end{array}$ & $\begin{array}{l}\text { Initial denaturation at } 95^{\circ} \mathrm{C} \text { for } 15 \text { min followed by } 35 \text { cycles of heat } \\
\text { denaturation at } 94{ }^{\circ} \mathrm{C} \text { for } 45 \mathrm{sec} \text {, primer annealing at } 55^{\circ} \mathrm{C} \text { for } 45 \mathrm{sec} \\
\text { and DNA extension at } 68^{\circ} \mathrm{C} \text { for } 2 \text { min. A final elongation step at } 72^{\circ} \mathrm{C} \\
\text { for } 5 \text { min. }\end{array}$ & 194 & [29] \\
\hline EPEC & EaeA & $\begin{array}{l}\text { TCAATGCAGTTCCGTTATCAGT } \\
\text { GTAAAGTCCGTTACCCCAACC TG }\end{array}$ & $\begin{array}{l}\text { An initial denaturation step at } 94{ }^{\circ} \mathrm{C} \text { for } 5 \mathrm{~min} \text {, followed by } 36 \text { cycles of } \\
94{ }^{\circ} \mathrm{C} \text { for } 35 \mathrm{sec} \text {, annealing at } 62{ }^{\circ} \mathrm{C} \text { for } 30 \mathrm{sec} \text { and elongation at } 72{ }^{\circ} \mathrm{C} \text { for } \\
1 \mathrm{~min} \text {. A final elongation step at } 72{ }^{\circ} \mathrm{C} \text { for } 5 \mathrm{~min} \text {. }\end{array}$ & 482 & [28] \\
\hline ETEC & $L t$ & $\begin{array}{l}\text { GCACACGGA GCTCCTCAGTC } \\
\text { TCCTTCATCCTTTCAATGGCTT }\end{array}$ & $\begin{array}{l}\text { An initial denaturation step at } 94{ }^{\circ} \mathrm{C} \text { for } 5 \mathrm{~min} \text {, followed by } 36 \text { cycles of } \\
94{ }^{\circ} \mathrm{C} \text { for } 35 \mathrm{sec} \text {, annealing at } 62{ }^{\circ} \mathrm{C} \text { for } 30 \mathrm{sec} \text { and elongation at } 72{ }^{\circ} \mathrm{C} \\
\text { for } 1 \mathrm{~min} \text {. A final elongation step at } 72{ }^{\circ} \mathrm{C} \text { for } 5 \text { min. }\end{array}$ & 218 & [28] \\
\hline UPEC & PapC & $\begin{array}{l}\text { GACGGCTGTACTGCAGGGTGTGGCG } \\
\text { ATATCCTTTCTGCAGGGATGCAATA }\end{array}$ & $\begin{array}{l}\text { An initial denaturation step at } 94{ }^{\circ} \mathrm{C} \text { for } 5 \mathrm{~min} \text {, followed by } 36 \text { cycles of } \\
94{ }^{\circ} \mathrm{C} \text { for } 35 \mathrm{sec} \text {, annealing at } 62^{\circ} \mathrm{C} \text { for } 30 \mathrm{sec} \text { and elongation at } 72{ }^{\circ} \mathrm{C} \\
\text { for } 1 \mathrm{~min} \text {. A final elongation step at } 72{ }^{\circ} \mathrm{C} \text { for } 5 \text { min. }\end{array}$ & 328 & [30] \\
\hline
\end{tabular}




\subsection{Gel Electrophoresis}

The PCR products (10 $\mu \mathrm{L}$ aliquots) were resolved in $1.8 \%$ agarose gel containing $5 \mu \mathrm{L}$ ethidium bromide in 1× TAE buffer (40 mM Tris-HCl, $20 \mathrm{mM}$ Na-acetate, $1 \mathrm{mM}$ EDTA, pH 8) [27,31] before being visualized and photographed under the Alliance 4.7 XD-79 System (Uvitec, Cambridge, UK). A 100-bp DNA ladder was included on each gel as a molecular size standard. The electrophoresis was carried out at $100 \mathrm{~V}$ for $1 \mathrm{~h}$.

\section{Results and Discussion}

\subsection{Isolation and Identification}

\subsubsection{Biochemical Confirmation}

There were 100 (50\%) Gram negative rods, catalase positive and oxidase negative in dairy farm A samples and $88(44 \%)$ in dairy farm B. In dairy farm A, $72(72 \%)$ were identified as E. coli using API 20E while dairy farm B, showed 68 (77\%) E. coli (Table 2). Species identity by API ranged from $76.8 \%$ to $99.9 \%$ in dairy farm B and $76.8 \%$ to $100 \%$ in dairy farm A.

Table 2. Table showing how organisms were identified from biochemical tests to molecular conformation.

\begin{tabular}{cccccccc}
\hline \multirow{2}{*}{ Farms } & \multicolumn{2}{c}{ Number of Samples } & G (-ve) & Cat & Ox & API & uidA Gene \\
\cline { 2 - 5 } & $\begin{array}{c}\text { Clinical } \\
\text { Mastitis }\end{array}$ & $\begin{array}{c}\text { Sub-Clinical } \\
\text { Mastitis }\end{array}$ & $\begin{array}{c}\text { Rods } \\
\text { (neg) }\end{array}$ & $\mathbf{2 0 E}$ & \\
\hline $\mathrm{A}$ & 100 & 100 & 100 & 100 & 100 & 72 & 50 \\
\hline $\mathrm{B}$ & 100 & 100 & 88 & 88 & 88 & 68 & 37 \\
\hline
\end{tabular}

Legends: G (-ve) = Gram Negative; Cat (pos) = Catalase positive; Ox (neg) = Oxidase negative. All Gram negative rods were obtained from cows showing Clinical Mastitis.

\subsubsection{Molecular Characterization of E. coli}

Isolates that were Gram negative, oxidase negative, and catalase positive were screened for E. coli uidA gene using PCR assays. Dairy farm B showed 50 (57.5\%) uidA gene amplification while dairy farm A showed 37 (42.5\%) amplification (Table 2; Figure 1). Amplification of several genes representing E. coli pathotypes is shown in Figure 1. The E. coli isolates that were positive by PCR for $f l i C H 7$, eae, lt, papC, ial, and eagR genes are summarized in Table 3. Dairy farm A had the highest amount of virulence genes compared to dairy farm B except for $l t$ gene, usually found in ETEC which was higher (13.5\%) in farm B. The target gene of E. coli $\mathrm{O} 157: \mathrm{H} 7$ (fliCH7) was noticed in the isolates obtained from both dairy farms in high amounts in comparison to other virulence genes. Farm A is situated next to a wastewater treatment plant and the discharged final effluent is used to clean the clusters, milking machines, milking utensils and the floor of the milking parlour this could explain the high occurrence of pathogenic E. coli in this farm. Also the milking parlour is cleaned once a day in this farm, whereas in farm B it is cleaned twice a day after every milking activity. Cattle faeces were 
observed around the farm floor, milking and feeding equipments. Poor hygiene of feeding equipment and contaminated feed plays an important role in milk contamination.

Table 3. Occurrence of pathogenic E. coli isolates from two dairy farms as indicated by presence of the target gene marker.

\begin{tabular}{cccccccc}
\hline \multirow{2}{*}{ Location } & \multicolumn{7}{c}{ Amplified Genes } \\
\cline { 2 - 7 } & uidA & fliCH7 & eae & $\boldsymbol{l t}$ & papC & Ial & eagR \\
\hline Dairy farm A & $50(57.5 \%)$ & $27(54 \%)$ & $9(18 \%)$ & $2(4 \%)$ & $3(6 \%)$ & $4(8 \%)$ & $5(10 \%)$ \\
Dairy farm B & $37(42.5 \%)$ & $16(43.2 \%)$ & $9(24.3 \%)$ & $5(13.5 \%)$ & $1(2.7 \%)$ & $2(5.4 \%)$ & $4(10.8 \%)$ \\
Total & $87(100 \%)$ & $43(49 \%)$ & $18(21 \%)$ & $7(8 \%)$ & $4(4.6 \%)$ & $6(7 \%)$ & $9(10.3 \%)$ \\
\hline
\end{tabular}

Figure 1. A representative gel showing all the genes amplified in this study.

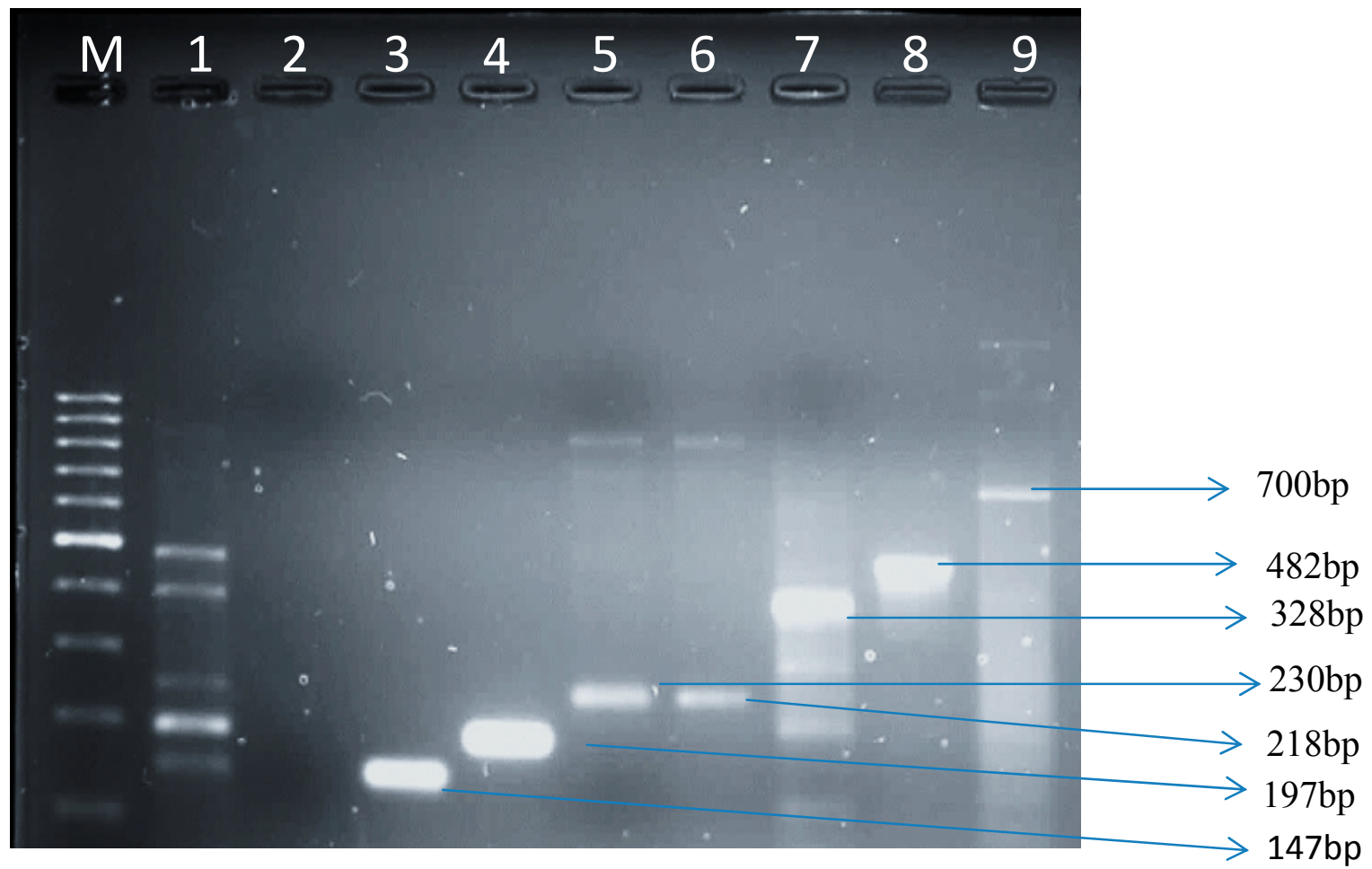

$\mathrm{M}=\mathrm{A} 100 \mathrm{bp}$ molecular marker; $1=$ positive controls of 6 of the amplified genes (band $1-E$. coli ATCC 8739; band 2-DSM 10974 (EAEC); band 3-DSM 10973 (ETEC); band 4-DSM 4618 (UPEC); band 5-DSM 8695 (EPEC); band 6-DSM 9025 (EIEC)); 2 = negative control (PCR assayed nuclease free water); 3 = uid gene (E. coli); $4=$ eagg (EAEC) gene; $5=$ fliCh7 (EHEC) gene, $6=l t$ (ETEC) gene; $7=\operatorname{pap} C(\mathrm{UPEC}) ; 8=e a e(\mathrm{EPEC})$ gene; $9=$ ial $(\mathrm{EIEC})$ gene.

Mastitis in lactating dairy cows is commonly caused by E. coli strains. The severity and course of mastitis differs enormously depending on the individual cow's response. However, the strain virulence may also play a role. The ability of $E$. coli to pick up DNA from the environment and therefore virulence genes are well demonstrated [32]. E. coli has been regarded as an indicator of fecal contamination [33], however, in the milk industry; it is regarded as poor hygiene indicator and insufficient sanitary practices during milking [34]. Raw unpasteurized milk can be an important source of food-borne pathogens because it harbors a variety of microorganisms while bulk tank raw milk may be contaminated by udder excretion of infected animals [35]. Unpasteurized milk is used to produce 
several types of cheese $[35,36]$. Consumption of unpasteurized and pasteurized milk has been blamed for disease in humans [37].

\subsubsection{Virulence Genes from E. coli Isolates in Raw Cow's Milk}

Different virulence genes were isolated from E. coli in diarrheic stools and water [38]. We based our selection of virulence genes for this study on their association with E. coli strains causing extra-intestinal and intestinal infections. There are no biochemical difference between bovine mastitis E. coli strains and faecal strains. Approximately $30.3 \%$ of the isolates in our study did not show amplification of examined genes. This might be indication that E. coli strains associated with mammary gland infections may use different mechanisms to cause diseases [39]. In another study, E. coli isolates (10.7\%) from bovine mastitis were found to have a single virulence gene [40]. Several virulence factors have been identified in bovine mastitis associated E. coli isolates [41] but many bovine mastitis isolates lack any of the virulence factors [42].

In our study all of the isolates were stx 1 and stx 2 negative. This result is similar to the results of [43,44] where stx 1 and 2 were not detected from bovine mastitis. This might not be a true reflection of the results since sub-types of stx 1 and stx 2 were not tested. The fliCH7 gene is one of the genes used as a marker to identify E. coli $\mathrm{O} 157: \mathrm{H7}$ [45] has been amplified from 27 (54\%) samples from farm A and $16(43.2 \%)$ from dairy farm B. This gene has also been isolated in E. coli from water by Okoh and Osode [46]. Although fliCH7 gene's associated with mastitis has not been isolated from cows with mastitis in South Africa, its association with severe clinical symptoms, including hemolytic colitis, hemolytic-uremic syndrome (HUS) and diarrhea have been well established [47,48]. Yogurt made on a farm from pasteurized milk was implicated in people affected by E. coli $\mathrm{O} 157: \mathrm{H} 7$, causing HUS cases among children [49]. Therefore, its presence in raw milk is a cause for concern.

The $l t$ gene which encodes for heat-labile toxin, found in Enterotoxigenic E. coli [50] was amplified from $2(4 \%)$ isolates in dairy farm B and $5(13.5 \%)$ dairy farm A. These results are different from what Frank et al. [51] reported (3.2\%) of ETEC strains in milk and milk products. As far as we know heat-labile toxin has never been shown to be associated with mastitis. However, the organism that produces heat-labile toxin, Enterotoxigenic E. coli (ETEC), causes infantile and travelers' in humans from developed to underdeveloped countries [52]. Contaminated food including milk and water serves as a route of infection for ETEC [53]. The disease manifests as a severe cholera-like syndrome [53,54]. This gene has also been detected E. coli from water [38].

The ial gene (a marker for the virulence plasmid pInv) which is found in Enteroinvasive E. coli was also amplified from $4(8 \%)$ isolates in dairy farm A and $2(5.4 \%)$ isolates from dairy farm B. Contaminated food and water have been implicated in the transmission of EIEC [55,56] even though person-to-person cases of EIEC have been noted [57]. When this organism is ingested, invasion and adhesion of the epithelial cells in the intestine mediated by the ial gene occurs. The characteristics of the illness are the appearance of blood and mucus in a condition called colitis of infected individuals [58]. Diarrhea, abdominal cramps, fever, a generalized malaise, vomiting, chills, are some of the symptoms. Outbreaks have been associated with hamburger meat and unpasteurized milk [59]. This is the first report where EIEC has been isolated from raw milk in the Eastern Cape Province of South Africa. Enteroaggregative E. coli was isolated and eagR amplified from $5(10 \%)$ isolates in dairy farm A and 
$4(10.8 \%)$ isolates from dairy farm B. Human clinical, animal, and environmental samples are some of the samples where this organism has been increasingly isolated and characterized around the world [60,61]. However, frequencies of Enteroaggregative Escherichia coli among cattle in the Eastern Cape Province, South Africa, are not known.

The virulence factor, eae, is associated with EPEC strains, defined as Stx-negative E. coli strains able to cause "attaching and effacing" (A/E) lesions, and also characterized by bacterial adherence to the intestinal epithelium intimately [62]. The eaeA and bfp genes have been used for identification of EPEC [63]. In our study, the ratio of eae was 9 (24.3\%) in dairy farm B and 9 (18\%) isolates in dairy farm A. However, in our study, we did not find any evidence of $b f p$ in all the isolates tested. Our results inform us that the isolated organisms were atypical EPEC as they lacked the gene $b f p$. The presence of this pathogen in milk proved to be variable in different regions. In Brazil, Aleixo and Aver [64] reported EPEC in 25\% milk samples while 26 (27.7\%) from bulk milk were EPEC in Trinidad [65]. These values were higher than the 3.09\% reported by Holko et al. [66] from Slovakia and that of Altalhi and Hussen [41], Saudi Arabia. EPEC strains are the oldest recognized category of diarrheagenic E. coli [67] and are well known prominent cause of diarrhea, particularly in children in less developed countries [68].

Uropathogenic E. coli (UPEC) which contain papC characterized as one of the pathogenic gene associated with the adhesion of UPEC to the upper urinary tract in humans [2] was amplified in three $(6 \%)$ isolates from dairy farm A and one $(2.7 \%)$ isolate in dairy farm B. The papC gene was reported to be associated with persistent mastitis by Dogan et al. [69]. Ingestion of milk contaminated with UPEC it can lead to cystitis in the bladder and acute pyelonephritis in the kidneys [3,70].

Act, No. 54 of 1972 in South Africa governs the safety of milk, and sets standards to which milk and dairy products, foodstuffs, cosmetics and disinfection must conform to. According to this Act milk may not contain pathogenic organisms, extraneous matter, any inflammatory product or any substance which may render it unfit for consumption. Bacteriologically it may not contain more than 20 coliforms or any E. coli per $\mathrm{mL}$. This study indicates that raw milk samples from both dairy farm A and dairy farm B were not complying with the act and could be a course for public health concern as some pathogenic genes known to be associated with diarheagenic E. coli were detected.

\section{Conclusions}

The results obtained in this study shows that raw cow's milk available to consumers in the Eastern Cape, South Africa was contaminated with the pathogen E. coli. Regular washing of milker's hands and animal udders together with sterilization of utensils and dairy equipment, is highly recommended as strict preventive measures. This might help in suppression of mastitis disease from the herd. Teaching and training programs for those working at the dairies can possibly improve the situation.

\section{Acknowledgments}

The National Research Foundation (NRF) of South Africa for funding this study. 


\section{Author Contributions}

Lesley-Anne Caine designed and supervised the experiment as well as the bacteriological analysis and drafted the manuscript. Ezekiel Green was the project leader of Mastitis investigation and performed the field work, designed and supervised the experiment as well as the bacteriological analysis. Uchechukwu Uchechukwu Nwodo performed the molecular experiments and analysis. Anthony Ifeanyi Okoh and Roland Ndip Ndip added value through introduction of critical technical considerations. All authors read and approved the final manuscript.

\section{Conflicts of Interest}

The authors declare no conflict of interest.

\section{References}

1. Bélanger, L.A.; Garenaux, J.; Harel, M.; Boulianne, E.; Dozois, C. Escherichia coli from animal reservoirs as a potential source of human extraintestinal pathogenic Escherichia coli. Fems Immunol. Med. Microbiol. 2011, 62, 1-10.

2. Croxall, G.; Hale, J.; Weston, V.; Manning, G.; Cheetham, P.; Achtman, M.; McNally, A. Molecular epidemiology of extraintestinal pathogenic Escherichia coli isolates from a regional cohort of elderly patients highlights the prevalence of ST131 strains with increased antimicrobial resistance in both community and hospital care settings. J. Antimicrob. Chemother. 2011, 66, 2501-2508.

3. Croxen, M.A.; Finlay, B.B. Molecular mechanisms of Escherichia coli pathogenicity. Nat. Rev. 2010, 26-38.

4. Kaper, J.B.; Nataro, J.P.; Mobley, H.L.T. Pathogenic Escherichia coli. Nat. Rev. Microbiol. 2004, 2, 123-140.

5. Russo, T.A.; Johnson, J.R. Proposal for a new inclusive designation for extraintestinal pathogenic isolates of Escherichia coli: ExPEC. J. Infect. Dis 2002, 181, 1753-1754.

6. Bekal, S.; Brousseau, R.; Masson, L.; Préfontaine, G.; Fairbrother, J.M.; Harel, J. Rapid identification of Escherichia coli pathotypes by virulence gene detection with DNA microarray. J. Clin. Microbiol. 2003, 41, 2113-2125.

7. Huang, D.B.; Mohanty, A.; DuPont, H.L.; Okhuysen, P.C.; Chiang, T. A review of emerging enteric pathogen: Enteroaggregative Escherichia coli. J. Med. Microbiol. 2006, 1303-1311.

8. Trabulsi, L.R.; Keller, R.; Gomes, T.A.T. Typical and atypical enteropathogenic Escherichia coli. Emerg. Infect. Dis. 2002, 8, 508-513.

9. Campellone, K.G. Cytoskeleton-modulating effectors of enteropathogenic and enterohaemorrhagic Escherichia coli: Tir, EspFU and actin pedestal assembly. Febs J. 2010, 277, 2390-2402.

10. Parsot, C. Shigella spp. and enteroinvasive Escherichia coli pathogenicity factors. Fems Microbiol. Lett. 2005, 252, 11-18.

11. Piekrard, D.; Stevens, D.; Moriau, L.; Lior, H.; Lauwers, S. Isolation and virulence factors of Verocytotoxin producing Escherichia coli in human stool samples. Clin. Microbiol. Infec. 1997, 3, 531-540. 
12. Bielaszewska, M.; Middendorf, B.; Kock, R.; Friedrich, A.W.; Fruth, A.; Karch, H.; Schmidt, A.; Mellmann, A. Shiga toxin-negative attaching and effacing Escherichia coli: Distinct clinical associations with bacterial phylogeny and virulence traits and inferred in-host pathogen evolution. Clin. Infect. Dis. 2008, 47, 208-217.

13. Stephan, R.; Schumacher, S.; Corti, S.; Krause, G.; Danuser, J.; Beutin, L. Prevalence and characteristics of shiga toxin-producing Esherichia coli in Swiss raw milk cheeses collected at producer level. J. Dairy Sci. 2008, 91, 2561-2565.

14. Arisoy, M.; Ayasev, D.; Ekim, M. Detection of virulence factors of Escherichia coli from children by multiplex polymerase chain reaction. Int. J. Clin Pract. 2006, 60, 170-173.

15. Yamamoto, S. Molecular epidemiology of uropathogenic Escherichia coli. J. Infect. Chemother. 2007, 13, 68-73.

16. Hagan, E.C.; Mobley, H.L. Uropathogenic Escherichia coli outer membrane antigens expressed during urinary tract infection. Infect. Immun. 2007, 75, 3941-3949.

17. Belanger, S.D.; Boissinot, M.; Menard, C.; Picard, F.J.; Bergeron, M.G. Rapid detection of Shiga toxin-producing bacteria in feces by multiplex PCR with molecular beacons on the smart cycler. J. Clin. Microbiol. 2002, 40, 1436-1440.

18. Gilgen, M.; Hubner, P.; Hofelen, C.; Luthy, J.; Candrian, U. PCR-based detection of verotoxin producing Esherichia. coli (VTEC) in ground beef. Res. Microbiol. 1998, 149, 145-154.

19. Fagan, P.K.; Hornitzky, M.A.; Bettelheim, K.A.; Djordjevic, S.P. Detection of Shiga-like toxin (stx1 and stx2), intimin (eaeA), and enterohemorrhagic Escherichia coli (EHEC) hemolysin (EHEC hlyA) genes in animal feces by multiplex PCR. Appl. Environ. Microbiol. 1999, 65, 868-872.

20. Rappelli, P.; Maddau, G.; Mannu, F.; Colombo, M.; Fiori, P.L.; Cappuccinelli, P. Development of a set of multiplex PCR assays for the simultaneous identification of enterotoxigenic, enteropathogenic, enterohemorrhagic and enteroinvasive Escherichia coli. New Microbiol. 2001, 24, 77-83.

21. Chapman, P.A.; Cerdan, A.; Malo, A.T.; Ellin, M.; Ashton, R.; Harkin, M.A. Escherichia coli O157 in cattle and sheep at slaughter, on beef and lamb carcasses and in raw beef and lamb products in south Yorkshire, UK. Int. J. Food Microbiol. 2001, 64, 139-150.

22. Chirsten, G.L.; Davidson, P.M.; McAllister, J.S.; Roth, L.A. Coliform and other indicator bacteria. In Standard Methods for the Examination of Dairy Products, 16th ed.; Marshall, R.T., ed.; American Public Health Association: Washington, DC, USA, 1993; Chapter 7, pp. 247-269.

23. Houghtby, G.A.; Maturin, L.J.; Koenig, E.K. Microbiological count methods. In Standard Methods for the Examination of Dairy Products, 16th ed.; Marshall, R.T., Ed.; American Public Health Association: Washington, DC, USA, 1993; Chapter 6, pp. 213-246.

24. Maugeri, T.L.; Carbone, M.; Fera, M.T.; Irrera, G.P.; Gugliandolo, C. Distribution of potentially pathogenic bacteria as free-living and plankton-associated in a marine coastal zone. J. Appl. Microbiol. 2004, 97, 354-361.

25. López-Saucedo, C.; Cerna, J.F.; Villegas-Sepulveda, N.; Thompson, R.; Velazquez, F.R.; Toress, J.; Tarr, P.I.; Estrada-Garda, T. Single multiplex polymerase chain reaction to detect diverse loci associated with diarrhoeagenic Escherichia coli. Emerg. Infect. Dis. 2003, 9, 127-131.

26. Tsai, L.Y.; Palmer, C.L.; Sangeermano, L.R. Detection of Escherichia coli in sludge by polymerase chain reaction. Appl. Environ. Microbiol. 1993, 59, 353-357. 
27. Wang, G.; Clifford, G.C.; Frank, G.R. Detection in Escherichia coli of the genes encoding the major virulence factors, the genes defining the O157:H7 serotype, and components of the type 2 shiga toxin family by multiplex PCR. J. Clin. Microbiol. 2002, 40, 3613-3619.

28. Stacy-Phipps, S.J.; Mecca, J.; Weiss, J.B. Multiplex PCR assay and simple preparation method for stool specimens detect enterotoxigenic Escherichia coli DNA during the course of infection. J. Clin. Microbiol. 1995, 33, 1054-1059.

29. Kong, R.Y.C.; Lee, S.K.Y.; Law, T.W.F.; Law, S.H.W.; Wu, R.S.S. Rapid detection of six types of bacterial pathogens in marine waters by multiplex PCR. Water Res. 2002, 36, 2802-2812.

30. Vidal, R.; Vidal, M.; Lagos, R.; Levine, M.; Prado, V. Multiplex PCR for diagnosis of enteric infections associated with diarrheagenic Escherichia coli. J. Clin. Microbiol. 2004, 42, 1787-1789.

31. Cagney, C.H.; Crowley, G.; Duffy, J.J.; Sheridan, S.; O’Brien, E.; Carney, W.M.; Anderson, D.A.; Dowell, I.; Blair, S.; Bisho, R.H. Prevalence and numbers of Escherichia coli O157:H7 in minced beef and beef burgers from butcher shops and supermarkets in the Republic of Ireland. J. Food Microbiol. 2004, 21, 203-212.

32. Dozois, C.M.; Curtiss, R., 3rd. Pathogenic diversity of Escherichia coli and the emergence of exotic' islands in the gene stream. Vet. Res. 1999, 30, 157-179.

33. Odonkor, S.T.; Ampofi, J.K. Escherichia coli as an indicator of bacteriological quality of water: An overview. Microbiol. Res. 2013, 4, 1-11.

34. Farzan, A.; Friendship, R.M.; Cook, A.; Pollari, F. Occurrence of Salmonella, Campylobacter, Yersinia enterocolitica, Escherichia coli $\mathrm{O} 157$ and Listeria monocytogenes in swine. Zoonoses Public Health 2010, 57, 388-396.

35. Oliver, S.P.; Jayarao, B.M.; Almedia, R.A. Food borne pathogens in milk and the dairy environment food safety and public health implications. Foodborne Pathog. Dis. 2005, 2, 1115-1129.

36. Collins, C.H.; Lyne, P.M.; Grange, J. Microbiological Methods; Collins, C.H., Lyne, P.M., Grange, J., Falkinham III, J. O., Eds.; Butterworth-Heinemann: London, UK, 1995.

37. Guh, A.; Phan, Q.; Nelson, R.; Purviance, K.; Milardo, E.; Kinney, S.; Mshar, P.; Kasacek, W.; Cartter, M. Outbreak of Escherichia coli $\mathrm{O} 157$ associated with raw milk, Connecticut, 2008. Clin. Infect. Dis. 2010, 51, 1411-1417.

38. Okoh, A.I.; Osode, A.N. Enterotoxigenic Escherichia coli (ETEC): A recurring decimal in infants' and travelers' diarrhea. Rev. Environ. Health 2008, 23, 135-148.

39. Blum, S.; Sela, N.; Heller, E.D.; Sela, S.; Leitner, G. Identification of a bovine mastitis Escherichia coli subset. Vet. Microbiol. 2008, 132, 135-148.

40. Wenz, J.R.; Barrington, G.M.; Garry, F.B.; Ellis, R.P.; Magnuson, R.J. Escherichia coli isolates serotypes, genotypes, and virulence genes and clinical coliform mastitis severity. J. Dairy Sci. 2006, 89, 3408-3412.

41. Altalhi, A.D.; Hassan, S.A. Bacterial quality of raw milk investigated by Escherichia coli and isolates analysis for specific virulence-gene markers. Food Control 2009, 20, 913-917.

42. Ghanbarpour, R.; Oswald, E. Phylogenetic distribution of virulence genes in Escherichia coli isolated from bovine mastitis in Iran. Res. Vet. Sci. 2010, 88, 6-10.

43. Bean, A.; Williamson, J.; Cursons, R.T. Virulence genes of Escherichia coli strains isolated from mastitic milk. J. Vet. Med. B-Infect. Dis. Vet. Public Health 2004, 51, 285-287. 
44. Dogan, B.; Klaessig, S.; Rishniw, M.; Almeida, R.A.; Oliver, S.P.; Simpson, K.; Schukken, Y.H. Adherent and invasive Escherichia coli are associated with persistent bovine mastitis. Vet. Microbiol. 2006, 116, 270-282.

45. Kumar, A.; Grover, S.; Batish, B.K. Application of multiplex PCR assay based on uidR and fliCH7 genes for detection of Escherichia coli O157:H7 in milk. J. General Appl. Microbiol. 2013, 59, 11-19.

46. Osode, A.N.; Okoh, A.I. Survival of free-living and plankton-associated Escherichia coli in the final effluents of a waste water treatment facility in a peri-urban community of the Eastern Cape Province of South Africa. Afr. J. Micobiol. Res. 2010, 4, 1424-1432.

47. Bettelheim, K.A. Role of non-O157 VTEC. J. Appl. Microbiol. 2000, 88, S38-S50.

48. Elliott, E.J.; Robins-Browne, R.M.; O’Loughlin, E.V.; Bennett-Wood, V.; Bourke, J.; Henning, P.; Hogg, G.G.; Knight, J.; Pouch, H.; Redmond, D. Nationwide study of haemolytic uraemic syndrome: Clinical, microbiological, and epidemiological features. Arch. Dis Child. 2001, 85, 125-131.

49. Murinda, S.E.; Nguyen, L.T.; Man, H.M.; Almedia, R.A. Detection of sorbitol negative and sorbitol-positive shiga toxin-producing Escherichia coli, Listeria monocytogenes, Campylobacter jejuni and Salmonella species in dairy farm environments. Foodborne Pathog. Dis. 2004, 1, 97-104.

50. Ruan, X.; Crupper, S.S.; Schultz, B.D.; Robertson, D.C.; Zhang, W. Escherichia coli expressing EAST1 toxin did not cause an increase of cAMP or cGMP levels in cells, and no diarrhea in 5-day old gnotobiotic pigs. PLoS One 2012, doi:10.1371/journal.pone.0043203.

51. Frank, V.; Hahn, G.; Tolle, A. Incidence and identification of enterotoxigenic Escherichia coli strains in milk and milk products. Zentral. Bakteriol. Microbiol. Hyg. 1984, 257, 51-59.

52. Ericsson, C.D. Travelers' diarrhea. Int. J. Antimicrobial Agents 2003, 21, 116-124.

53. Foodborne Disease Outbreaks: Guidelines for Investigation and Control; World Health Organization: Geneva, Switzerland, 2007; p. 21.

54. Evans, D.J.; Evans, D.G., Jr. Colonization factor antigens of human pathogens. Current topicsEscherichia coli in diarrheal disease. Microbiol. Immun. 1990, 151, 129-145.

55. Gordillo, M.E.; Reeve, G.R.; Pappas, J.; Mathewson, J.J.; DuPont, H.L.; Murray, B.E. Molecular characterization of strains of enteroinvasive Escherichia coli O143, including isolates from a large outbreak in Houston, Texas. J. Clin. Microbiol. 1992, 30, 889-893.

56. Marier, R.; Wells, J.G.; Swanson, R.C.; Dalthan, W.; Mehlman, I.J. An outbreak of enteropathogenic Escherichia coli food borne disease traced to imported French cheese. Lancet 1973, 302, 1376-1378.

57. Harris, J.R.; Mariano, J.; Wells, J.G.; Payne, B.J.; Donnell, H.D.; Cohen, M.L. Person-to-person transmission in an outbreak of enteroinvasive Escherichia coli. Amer.J. Epidemol. 1985, 122, 245-252.

58. Todar, K. Pathogenic Escherichia coli. In Todar's Online Textbook on Bacteriology; Department of Bacteriology, University of Wisconsin: Madison, WI, USA, 2008.

59. Lan, R.; Alles, M.C.; Donohoe, K.; Martinez, M.B.; Reeves, P.R. Molecular evolutionary relationships of enteroinvasive Escherichia coli and Shigella spp. Infect. Immun. 2004, 72, 5080-5088. 
60. Kahali, S.; Sarkar, B.; Rajendran, K.; Khanam, J.; Nandy, S.R.K.; Bhattacharya, S.K.; Ramamurthy, T. Virulence characteristics and molecular epidemiology of enteroaggregative Escherichia coli isolates from hospitalized diarrheal patients in Kolkata, India. J. Clin. Microbiol. 2004, 42, 4111-4120.

61. Yamamoto, T.; Nakazawa, M. Detection and sequences of the Enteroaggregative Escherichia coli heat-stable enterotoxin 1 gene in enterotoxigenic E. coli strains isolated from piglets and calves with diarrhea. J. Clin. Microbiol. 1997, 35, 223-227.

62. Vallance, B.A.; Finlay, B.B. Exploitation of host cells by enteropathogenic Escherichia coli. Proc. Nat. Acad. Sci. USA 2000, 97, 8799-8806.

63. Bugarel, M.; Martin, A.; Fach, P.; Beutin, L. Virulence profiling of enterohemorrhagic (EHEC) and enteropathogenic (EPEC) Escherichia coli strains: A basis of molecular risk assessment of atypical and typical EPEC strains. BMC Micobiol. 2011, 11, doi:10.1186/1471-2180-11-142

64. Aleixo, J.A.; Aver, G.P. Prevalence of enteropathogenic and enterotoxigenic Escherichia coli in foods of animal origin in southern Brazil. Ciência. Rural 1996, 26, 1121-1129.

65. Adesiyun, A.; Webb, L.; Romain, H.; Kaminjolo, J. Prevalence and characteristics of strains of Escherichia coli isolated from milk and feces of cows on dairy farms in Trinidad. J. Food Protect. 1997, 60, 174-181.

66. Holko, I.; Bisova, T.; Holkova, Z.; Kmet, V. Virulence markers of Escherichia coli strains isolated from traditional cheeses made from unpasteurised sheep milk in Slovakia. Food Control 2006, 17, 393-396.

67. Zuber, M. E. coli: Serotypes other than O157:H7; MSPH DOH, Regional Epidemiologist: Tallahasse FL, USA, 1999.

68. Tennant, S.M.; Tauschek, M.; Azzopardi, K.; Bigham, A.; Bennett-Wood, V.; Hartland, E.L.; Qi, W.; Whittam, T.S.; Robins-Browne, R.M. Characterization of atypical enteropathogenic E. coli strains of clinical origin. BMC Microbiol. 2009, 9, doi:10.1186/1471-2180-9-117.

69. Dogan, B.; Rishniw, M.; Bruant, G.; Harel, J.; Schukken, Y.H.; Simpson, K.W. Phylogroup and lpfA influence epithelial invasion by mastitis associated Escherichia coli. Vet. Microbiol. 2012, 159, 163-170.

70. Alteri, C.J.; Hagan, E.C.; Sivick, K.E.; Smith, S.N.; Mobley, H.L.T. Mucosal immunization with iron receptor antigens protects against urinary tract infection. PLoS Pathog. 2009, 5, doi:10.13711/journal.ppat.1000586.

(C) 2014 by the authors; licensee MDPI, Basel, Switzerland. This article is an open access article distributed under the terms and conditions of the Creative Commons Attribution license (http://creativecommons.org/licenses/by/4.0/). 